\title{
USO POLÍTICO DOS INSTRUMENTOS DE DIREITO FINANCEIRO DEVE SER COMBATIDO
}

Coluna publicada em 25.7.2017: <https://www.conjur.com.br/2017-jul-25/ contas-vista-uso-politico-direito-financeiro-combatido $>$

A crise política que parece não cessar trouxe à tona uma antiga questão de Direito Financeiro, que evidencia a forte inter-relação entre esse ramo do Direito e a política: o uso impróprio das emendas parlamentares como meio para conseguir apoio do Poder Legislativo às medidas de interesse do Poder Executivo e/ou de seus membros.

Proliferaram nas últimas semanas notícias ${ }^{1}$ de que a votação que poderia receber a denúncia contra o Presidente Michel Temer motivou uma verdadeira "compra de votos" de parlamentares por meio da liberação de recursos que constam do orçamento inseridos por meio de emendas parlamentares.

O tema não é novo e, curiosamente, foi abordado na primeira coluna que escrevi para a seção Contas à Vista, publicada cinco anos atrás, no já longínquo dia 3 de julho de 2012 (Emendas ao orçamento e o desequilibrio de poderes ${ }^{2}$ ), quando o

1 Apenas para citar algumas: Liberação de emendas parlamentares dispara em junho após crise. Exame.com, 4 de julho de 2017 (<http://exame.abril.com.br/brasil/liberacao-de-emendas-parlamentares-dispara-em-junho-apos-crise/>); Após delação da JBS, governo dispara liberação de emendas parlamentares. Folha/UOL, 5 de julho de 2017 (<http://www1.folha.uol.com.br/ poder/2017/07/1898642-apos-delacao-da-jbs-governo-dispara-liberacao-de-emendas-parlamentares.shtml>). Diz a notícia, em certo trecho, que "A liberação de emendas é um dos mecanismos mais tradicionais que os governos lançam mão para garantir a fidelidade da base aliada"; e Governo federal libera R \$ 3,4 bi em emendas para garantir votos. Correio Braziliense, 23 de julho de 2017 (<http://www.correiobraziliense.com.br/app/noticia/politica/2017/07/23/ internas_polbraeco,611773/governo-federal-libera-r-3-4-bi-em-emendas-para-garantir-votos. shtml>).

2 Nesta edição, p. 219-222. 
"fator motivador" das liberações de recursos foi a formação da chamada "CPI do Cachoeira”, que a essa altura poucos devem se lembrar, perdida que ficou no meio de tantos e mais graves escândalos que se sucederam desde então.

Trata-se de uma interferência no ciclo orçamentário, em que, na fase legislativa de elaboração da lei orçamentária, os parlamentares, por meio de emendas ao projeto de lei, inserem no orçamento recursos para atender aos interesses de suas bases eleitorais. Aprovada a lei orçamentária, durante a fase de execução, os recursos contemplados por essas emendas ficam sujeitos a contingenciamentos, e a liberação acaba sendo condicionada a contrapartidas dos parlamentares, como, no caso noticiado, o apoio contra a autorização para que o Presidente da seja processado pela prática de crimes. ${ }^{3}$

Para coibir essa prática (ou ao menos tentar...), em 2015 foi aprovada a "PEC do Orçamento Impositivo" (Proposta de Emenda Constitucional 385/2013), que se materializou na Emenda Constitucional 86/2015, alterando a redação dos artigos 165 e 166 da Constituição para tornar obrigatória a execução das dotações orçamentárias que foram introduzidas pelas emendas parlamentares individuais (tratei do tema na coluna Aprovação do orçamento impositivo não dá credibilidade à lei orçamentária, nesta edição, p. 235-240). Ou seja, fez-se uma emenda constitucional que não só teve a curiosa finalidade de obrigar a cumprir uma lei - a lei orçamentária -, como se limitou a apenas exigir esse cumprimento para uma mínima parcela dela - os valores inseridos por emendas parlamentares, que correspondem a pouco mais de $1 \%$ do orçamento. E o pior, pelo que se vê, é que não surtiu o efeito esperado, uma vez que as notícias recentes dão conta de que a prática continua.

Este é um dos mais claros exemplos de uso político de instrumentos de Direito Financeiro, evidenciando que nesse ramo do Direito a política exerce forte in-

3 Como escrevi à época na citada coluna, "Uma vez que se sabem quais as dotaçôes orçamentárias inseridas no orçamento pelas emendas parlamentares, cuja liberação dos recursos é de evidente interesse do parlamentar que a patrocinou, o contingenciamento das referidas dotações, para liberação oportuna, transformou o processo orçamentário em verdadeiro instrumento de 'compra' de apoio político do Legislativo por parte do Executivo. As dotações consignadas às emendas parlamentares são liberadas, como se tem reiteradamente constatado, por razões de interesse político, e não financeiro. Desvia-se, dessa forma, o contingenciamento, instrumento de flexibilidade orçamentária destinado a melhor gerenciar o fluxo de recursos, de sua verdadeira finalidade, que é adaptar as inconstâncias da atividade financeira para buscar atingir o fiel cumprimento da lei orçamentária tal como aprovada, para outra que não lhe é própria, a saber, a de moeda de troca entre os Poderes por apoios políticos circunstanciais". 
fluência, por vezes até exagerada, a ponto de prejudicar a segurança jurídica que se espera das normas de Direito Financeiro.

Interessante notar que essa "pressão" que se faz por meio de instrumentos próprios do Direito Financeiro ocorre também em outro sentido, "contra” o Chefe do Poder Executivo.

Veja-se o recente caso da suspensão da emissão de passaportes pela Polícia Federal por falta de recursos, que motivou concessão de recursos adicionais por meio da abertura de créditos suplementares.

Nesse caso, tendo em vista que adotamos a técnica de "orçamento incrementativo", por meio do qual o orçamento é elaborado tendo por base o orçamento do ano anterior, é comum que as dotações sejam fixadas de maneira insuficiente, considerando o provável crescimento das despesas a cada ano. ${ }^{4}$ Uma técnica de todo conveniente para o Chefe do Poder Executivo, que fica, ao longo do exercício, com o poder altamente discricionário de promover a abertura de créditos adicionais destinados a suplementar as dotações - e mais uma oportunidade para que possa usar politicamente esse instrumento de Direito Financeiro.

No entanto, por vezes o provérbio "o feitiço vira contra o feiticeiro" se faz presente. Esgotada a dotação para os recursos destinados às despesas com a emissão de passaportes, a Polícia Federal simplesmente suspendeu a prestação do serviço público, justamente às vésperas das férias escolares e em um período de relações tensas entre o órgão e o Presidente. ${ }^{5}$ Um fato que chega a ser corriqueiro, repete-se praticamente todos os anos e é solucionado sem grandes alardes, passa ser manchete principal da mídia, causa transtorno a milhares de pessoas, e com isso o órgão "vitimado" pela falta de recursos consegue chamar a atenção para sua importância e a necessidade que tem de mais recursos. E é prontamente atendido pelo Presidente. ${ }^{6}$

Esse uso político dos instrumentos de Direito Financeiro permite entender porque tantos problemas podem ser causados por tão pouco, e dão pistas que facilitam compreender alguns fenômenos orçamentários. Em recente editorial, mani-

4 Crise econômica pode criar “orçamento recurso-zero", nesta edição, p. 241-244, e Natal é tempo de correr com a execução orçamentária, nesta edição, p. 211-214.

5 Congresso aprova crédito extra para regularizar emissão de passaportes. Folha de S.Paulo, 13 de julho de 2017 (<http://wwwl.folha.uol.com.br/cotidiano/2017/07/1901144-congresso-aprova-credito-extra-para-regularizar-emissao-de-passaportes.shtml >).

6 Temer sanciona projeto que libera R \$ 102 milhões para emissão de passaportes. EBC-Agência Brasil, 19 de julho de 2017 (<http://agenciabrasil.ebc.com.br/geral/noticia/2017-07/temer-sanciona-projeto-que-libera-r-102-milhoes-para-emissao-de-passaportes $>$ ). 
festou-se a Folha de S.Paulo: "Parece difícil entender como um governo cujo Orçamento supera o trilhão de reais tem dificuldades para reajustar o Bolsa Família ou, num exemplo mais prosaico, fornecer os passaportes requisitados - e pagos pelos cidadão do país. (...) Ambos os casos envolvem montantes pouco expressivos para os padrōes da despesa federal e, ao mesmo tempo, medidas essenciais. (...) Mesmo em meio à severa escassez de receitas, não deveria haver maior dificuldade em remanejar recursos de programas menos prioritários para atender a tais objetivos - o que afetaria menos de $0,1 \%$ dos gastos autorizados neste ano" ("Orçamento Insensato"). ${ }^{7}$

O orçamento, lei aprovada pelo Poder Legislativo, que deveria ter a palavra final em matéria de gastos públicos, precisa ser aperfeiçoado, bem como o processo orçamentário, para que não fique nas mãos do Poder Executivo, a quem caberia apenas cumpri-lo, o poder de alterá-lo e desfigurá-lo, como muitas vezes ocorre. ${ }^{8}$

O uso político dos instrumentos de Direito Financeiro em nada colabora para a confiabilidade nas instituiçõos, o aperfeiçoamento da democracia e respeito à vontade do povo em matéria de finanças públicas, e deve ser combatido. Como disse Eça de Queiroz, "a luta pelo dinheiro é santa"9 - mas até certo ponto e com moderação...

7 Folha de S. Paulo, editorial publicado em 5 de julho de 2017 (<http://www1.folha.uol.com.br/ opiniao/2017/07/1898537-orcamento-insensato.shtml>).

8 Durante as eleiçôes, pense bem para quem vai entregar a chave do cofre, nesta edição, p. 223-226.

9 "A luta pelo dinheiro é santa - porque é, no fundo, a luta pela liberdade: mas até uma certa soma. Passada ela - é a tristonha e baixa gula do ouro." 